\title{
PENGARUH WORKING CAPITAL, LIKUIDITAS, DAN OPERATING CASH FLOW TERHADAP PROFITABILITAS PADA PERUSAHAAN ANEKA INDUSTRI, INDUSTRI DASAR DAN KIMIA YANG TERDAFTAR BURSA EFEK INDONESIA
}

\author{
Yeni Rafita Sihombing ${ }^{1}$ \\ Yermi Br Hutabarat ${ }^{2}$ \\ 1,2) Jurusan Akuntansi Universitas Prima Indonesia \\ yeni.rafita@gmail.com ${ }^{1}$, yermibrhutabrat@gmail.com ${ }^{2}$
}

\begin{abstract}
ABSTRAK
Penelitian ini bertujuan untuk menguji dan menganalisis pengaruh working capital, likuiditas dan operating cash flow terhadap profitabilitas pada perusahaan aneka industri, industri dasar dan kimia. Pendekatan yang digunakan dalam penelitian ini adalah pendekatan kuantitatif. Teknik pengambilan sampel yang dilakukan adalah dengan menggunakan teknik purposive sampling. Data yang digunakan di dalam penelitian ini adalah data sekunder. Metode analisis yang digunakan dalam penelitian ini adalah analisis regresi berganda. Berdasarkan hasil yang diperoleh secara parsial menunjukkan bahwa terdapat pengaruh working capital tehadap profitabilitas, demikian juga likuiditas terhadap profitabilitas yang menunjukkan pengaruh positif dan signifikan, operating cash flow terhadap profitabilitas ditemukan bahwa operating cash flow tidak berpengaruh terhadap profitabilitas. Hasil penelitian menunjukkan bahwa secara simultan antara working capital, likuiditas dan operating cash flow memberikan kontribusi pengaruh terhadap profitabilitas.
\end{abstract}

Kata Kunci: Working Capital; Likuiditas; Operating Cash Flow; Profitabilitas

\section{ABSTRACT}

This study aims to test and analyze the influence of working capital, likuiditas and operating cash flow, on profitability in various industrial, basic and chemical companies This research used a qualitative research approach. The techique of data collection is using purposive sampling. The data is using secondary data. The data analysis method used in this research is the multiple linear regression analysis. Based on the results that partially shows that there is an effect of working capital on profitability, likewise, liquidity on profitability shows a positive and significant effect, and operating cash flow on profitabilty, it is found that operating cash flow on profitability does not give an influence. The results showed that simultaneously the working capital, liquidity and operating cash flow contributed to the effect of profitabilty.

Keywords: Working Capital; Liquidity; Operating Cash Flow; Profitability

\section{PENDAHULUAN}

Perusahaan merupakan sarana dan alat yang digunakan untuk menghasilkan keuntungan yang maksimal bagi pemilik. Semakin berkembangnya ekonomi, kepentingan atas sebuah perusahaan tidak terbatas pada pemilik saja, tetapi pihak lain seperti kreditur, investor dan calon investor dan bahkan masyarakat pun memiliki kepentingan atas sebuah perusahaan.

Perusahaan manufaktur sektor aneka industri, industri dasar dan kimia merupakan suatu usaha atau kegiatan pengolahan bahan mentah atau barang setengah jadi menjadi barang jadi yang memiliki nilai tambah untuk mendapat keuntungan atau laba. Pasar modal adalah salah satu alternatif yang dapat dimanfaatkan perusahaan untuk memenuhi kebutuhan dananya. Jika 
dilihat dari sisi investor, pasar modal merupakan salah satu sarana efektif bagi mereka untuk menanamkan modalnya agar dapat memperoleh keuntungan.

Pasar modal adalah salah satu alternatif yang dapat dimanfaatkan perusahaan untuk memenuhi kebutuhan dananya. Jika dilihat dari sisi investor, pasar modal merupakan salah satu sarana efektif bagi mereka untuk menanamkan modalnya agar dapat memperoleh keuntungan.

Profitabilitas merupakan kemampuan perusahaan memperoleh laba dalam hubungan dengan penjualan, total aktiva maupun modal sendiri. Profitabilitas dipengaruhi oleh banyak faktor. Dan manajer keuangan sebagai pengelola keuangan pada perusahaan perlu mengetahui faktor-faktor yang memiliki pengaruh besar terhadap profitabilitas perusahaan. Dengan mengetahui pengaruh dari masing-masing faktor terhadap profitabilitas, perusahaan dapat menentukan langkah untuk mengatasi masalah-masalah dan meminimalisir dampak negatif yang timbul.

Working capital sangat berpengaruh bagi suatu perusahaan. Adanya modal kerja yang cukup memungkinkan suatu perusahaan dalam melaksanakan aktivitasnya tidak mengalami kesulitan dan hambatan yang mungkin akan timbul. Perusahaan yang memiliki modal kerja yang berlebihan menunjukkan adanya dana yang tidak produktif dan hal ini memberikan kerugian karena dana yang tersedia tidak dipergunakan secara efektif dalam kegiatan perusahaan. Sebaliknya, kekurangan modal kerja merupakan sebab utama kegagalan perusahaan dalam menjalankan aktivitasnya.

Likuiditas juga memiliki peranan penting dalam profitabilitas perusahaan dan perusahaan yang dikatakan likuid adalah perusahaan yang memiliki kemampuan untuk memenuhi segala kewajiban finansialnya yang harus segera dipenuhi. Perusahaan memanfaatkan hutang sebagai sumber dana dengan harapan penggunaan hutang tersebut dapat memantu perusahaan dalam mencapai laba. Jika tidak dikelola dengan baik, hutang akan menimbulkan masalah bagi perusahaan.

Operating cash flow sangat penting bagi kemampuan perusahaan untuk menghasilkan laba. Masalah-masalah yang terjadi pada arus kas terjadi karena arus kas keluar lebih cepat atau lebih banyak dibanding arus kas masuk. Akan baik bagi perusahaan jika tidak memiliki hutang dan hanya memiliki aset operasi sehingga perusahaan akan memperoleh laba operasi bersih. Namun, yang perlu diperhatikan arus kas tidak dapat terus dipertahankan, sehingga aset tetap yang disusutkan harus diganti dengan produk baru juga perlu tetap dikembangkan. Dari uraian tersebut peneliti ingin membuktikan secara empiris apakah working capital, likuiditas, dan operating cash flow berpengaruh terhadap profitabilitas baik secara parsial dan secara simultan pada perusahaan aneka industri, industry dasar dan kimia yang terdaftar di Bursa Efek Indonesia.

\section{TINJAUAN PUSTAKA DAN PENGEMBANGAN HIPOTESIS}

\subsection{Working Capital}

Modal kerja adalah modal yang secara fungsional turut mendatangkan penghasilan pada periode berjalan seperti: kas, harga pokok dalam piutang usaha, persediaan dan penyusutan aktiva tetap (Sitanggang, 2014).

Modal kerja adalah harta yang dimiliki perusahaan yang dipergunakan untuk menjalankan kegiatan usaha atau membiayai operasional perusahaan tanpa mengorbnkan aktiva yang lain dengan tujuan memperoleh laba yang optimal (Ikhsan, Alfurkaniati, L, \& Dalimunthe, 2016). Perusahaan yang tidak memiliki kecukupan modal kerja akan sulit untuk menjalankan kegiatannya, atau macet operasinya. Tanpa modal kerja yang cukup, suatu perusahaan akan kehilangan kesempatan untuk meningkatkan kuantitas dan kualitas produk yang dihasilkan (Utari, Purwanti, \& Prawironegoro, 2014) 
Modal kerja memiliki arti yang sangat penting bagi opersional suatu perusahaan di samping itu, manajemen modal kerja juga memiliki beberapa tujuan tertentu yang hendak dicapai (Kasmir, 2012).

\subsection{Likuiditas}

Rasio likuiditas adalah kemampuan suatu perusahaan memenuhi kewajiban jangka pendeknya secara tepat waktu (Fahmi, 2015). Contoh membayar listrik, telefon, air PDAM, gaji karyawan, gaji teknisi, gaji lembur, dan sebagainya. Karena itu rasio likuiditas sering disebut dengan short term liquidity.

Llikuiditas merupakan ukuran kinerja perusahaan dalam kemampuan perusahaan untuk memenuhi kewajiban keuangan yang segera harus dilunasi yaitu kewajiban keuangan yang jatuh temponya sampai dengan 1 tahun (Sitanggang, 2014).

Rasio likuiditas berfungsi untuk menunjukkan atau mengukur kemampuan perusahaan dalam memenuhi kewajibannya yang sudah jatuh tempo, baik kewajiban kepada pihak luar perusahaan (likuiditas badan usaha) maupun di dalam perusahaan (likuiditas perusahaan) (Kasmir, 2012). Rasio likuiditas sering juga dikenal sebagai rasio modal kerja (rasio aset lancar), yaitu rasio yang digunakan untuk mengukur seberapa likuid suatu perusahaan. Rasio modal kerja dihitung dengan membandingkan antara total aset lancar dengan total kewajiban lancar. Pengukuran dan evaluasi terhadap rasio ini dapat dilakukan untuk beberapa periode sehingga dapat dilihat perkembangan kondisi tingkat likuiditas perusahaan dari waktu ke waktu (Hery, 2015).

\subsection{Operating Cash Flow}

Arus kas operasional yaitu arus kas yang terjadi karena operasi proyek tersebut, dan terjadi selama usia ekonomis proyek tersebut (Kamaludin, 2012).

Arus kas dari aktivitas operasi, adalah arus kas yang terutama diperoleh dari aktivitas penghasilan utamapendapatan perusahaan, oleh karena itu arus kas ini pada umumnya berasal dari transaksi dan peristiwa lain yang mempengaruhi pendapatan laba (rugi) bersih (Hantono, 2017). Grafik arus kas menggambarkan proporsi naik dan turunnya angka penjualan. Jika kondisi pasar menggembirakan maka penjualan perusahaan mengalami peningkatan, namun jika kondisi pasar tidak menggembirakan artinya grafik arus kas juga akan mengalami penurunan (Fahmi, 2016).

Dalam praktiknya selama perusahaan beroperasi terdapat dua macam aliran kas. Aliran kas masukmerupakan uang kas yang masuk ke perusahaan (penerimaan uang), misalnya perolehan pendapatan baik berupa hasil pejualan atau laba perusahaan. Uang kas masuk dapat pula diperoleh dari bunga yang diperoleh dari hasil investasi atau pendapatan di luar usaha serta dapat pula diperoleh dari pinjaman pihak lain (misalnya, bank) ataupun dana hibah. Adapun aliran kas keluar merupakan uang yang dikelurkan perusahaan untuk membiayai operasi perusahaan seperti untuk membeli bahan baku, membayar gaji, upah, pajak atau biaya operasional lainnya. Uang keluar dapat berupa sejumlah uang yang digunakan untuk melakukan investasi baik yang berkaitan dengan bidang usaha maupun tidak.

\subsection{Profitabilitas}

Rasio profitabilitas merupakan rasio yang digunakan untuk mengukur kemampuan perusahaan dalam menghasilkan laba dari aktivitas normal bisnisnya (Hery, 2014).

Rasio profitabilitas merupakan rasio untuk menilai kemampuan perusahaan dalam mencari keuntungan.Rasio ini juga memberikan ukuran tingkat evektivitas manajemen suatu perusahaan (Kasmir, 2012). Hal ini ditunjukkan oleh laba yang dihasilkan dari penjualan dan pendapatan investasi. Intinya adalah penggunaan rasio ini menunjukkan efisiensi perusahaan. 
Rasio profitabilitas bertujuan untuk mengukur efektivitas manajemen yang tercermin pada imbalan atas hasil investasi melalui kegiatan perusahaan atau dengan kata lain mengukur kinerja perusahaan secara keseluruhan dan efisiensi dalam pengelolaan kewajiban dan modal (Sugiono, 2016). Dari pernyataan diatas maka dapat disimpulkan bahwa arti penting profitabilitas merupakan menghitung tingkat kemampuan dalam memperoleh laba dan mengukur efisiensi penggunaan modal guna melihat keuntungan yang diperoleh dalam pengembalian yang pantas atas hutang dan modalnya yang bertujuan untuk meningkatkan nilai perusahaan.

\subsection{Kerangka Berpikir dan Pengembangan Hipotesis \\ 2.5.1.Pengaruh Working Capital Terhadap Profitabilitas}

Semakin banyak dana yang digunakan sebagai modal kerja seharusnya dapat meningkatkan perolehan laba. Demikian pula sebaliknya, jika dana yang digunakan sedikit, maka laba pun akan menurun. Akan tetapi dalam kenyataannya terkadang kejadiannya tidak selalu demikian (Kasmir, 2012). Semakin besar suatu perusahaan maka kebutuhan dana untuk menunjang modal kerja juga akan semakin tinggi, dan itu diikuti juga dengan harus semakin tinggi perputaran yang bisa diberikan agar tertutupinya biaya modal kerja yang telah dikeluarkan. Secara konsep ketika turnover penjualan semakin tinggi serta melewati batas biaya modal kerja yang dikeluarkan maka artinya perusahaan akan memperoleh keuntungan (profit), dan begitu pula sebaliknya (Fahmi, 2015).

$\mathrm{H}_{1}$ : Working Capital berpengaruh terhadap Profitabilitas

\subsubsection{Pengaruh Likuiditas Terhadap Profitabilitas}

Current ratio yang terlalu tinggi menunjukkan kelebihan uang kas dan aktiva lancar lainnya dibandingkan dengan yang dibutuhkan sekarang atau tingkat likuiditasnya yang lebih rendah dari pada aktiva lancar dan sebaliknya (Munawir, 2014). Semakin tinggi rasio ini adalah semakin baik artinya aktiva lancar dapat menutupi kewajiban lancar yang disebut likuid. Akan tetapi terlalu tinggi rasio ini juga tidak baik, karena perusahaan tidak dapat mengelola aktiva lancar dengan efektif (Sjahrial \& Purba, 2013).

$\mathrm{H}_{2}$ : Likuiditas berpengaruh terhadap Profitabilitas

\subsubsection{Pengaruh Operating Cash Flow Terhadap Profitabilitas}

Semakin tinggi rasio ini menunjukkan bahwa kinerja keuangan perusahaan semakin baik, meskipun dengan jumlah laba bersih yang kecil sebagai akibat besarnya beban non kas (Hery, 2015). Jumlah kas yang relatif kecil akan diperoleh tingkat perputaran kas yang tinggi dan keuntungan yang diperoleh akan lebih besar (Jumingan, 2015). Kelebihan uang pada suatu saat, melebihi kebutuhan perusahaan, menyebabkan terlalu banyaknya uang yang menganggur, padahal seharusnya uang tersebut dapat dikelola secara lebih optimal lagi untuk kepentingan perusahaan (Rudianto, 2009).

$\mathrm{H}_{3}$ : Operating Cash Flow berpengaruh terhadap Profitabilitas

\section{METODOLOGI PENELITIAN}

\subsection{Populasi dan Sampel}

Populasi adalah wilayah generalisasi yang terdiri atas objek/subjek yang memiliki kualitas dan karakteristik tertentu yang ditetapkan oleh peneliti untuk dipelajari dan ditarik kesimpulannya (Sugiyono, 2016). Populasi yang digunakan dalam penelitian ini adalah sebanyak 110 perusahaan aneka industri, industri dasar dan kimia di Bursa Efek Indonesia tahun 2014-2017. Sampel adalah bagian dari jumlah dan karakteristik yang dimiliki oleh populasi tersebut (Sugiyono, 2016). Teknik pengambilan sampel menggunakan purposive sampling. Teknik purposive sampling adalah teknik penentuan sampel dengan pertimbangan 
tertentu (Sugiyono, 2016) .Dalam penelitian ini, kriteria yang ditetapkan adalah sebagai berikut :

1. Perusahaan aneka industri, industri dasar dan kimia yang terdaftar di Bursa efek Indonesia

2. Perusahaan aneka industri, industri dasar dan kimia yang mempublikasikan laporan keuangan lengkap secara berturut-turut dari tahun 2014-2017.

3. Perusahaan aneka industri, industri dasar dan kimia yang mengalami keuntungan dari tahun 2014-2017.

Tabel 1. Proses Pemilihan Sampel

\begin{tabular}{|l|c|}
\hline \multicolumn{1}{|c|}{ Keterangan } & Jumlah \\
\hline $\begin{array}{l}\text { Perusahaan aneka indutri, indutri dasar dan kimia yang terdaftar di Bursa } \\
\text { efek indonesia }\end{array}$ & 110 \\
\hline $\begin{array}{l}\text { Perusahaan aneka industri, indutri dasar dan kimia yang tidak } \\
\text { mempublikasikan laporan keuangan lengkap secara berturut-turut dari } \\
\text { tahun 2014-2017 }\end{array}$ & $(19)$ \\
\hline $\begin{array}{l}\text { Perusahaan aneka indutri, indutri dasar dan kimia yang mengalami } \\
\text { kerugian dari tahun 2014-2017 }\end{array}$ & $(49)$ \\
\hline Jumlah Sampel Akhir & 42 \\
\hline Tahun Penelitian & 4 \\
\hline Total Sampel Penelitian & 168 \\
\hline
\end{tabular}

\subsection{Operasional Variabel}

Adapun operasional variabel - variabel yang digunakan dalam penelitian ini adalah sebagai berikut :

\subsubsection{Profitabilitas (Y)}

ROA melihat sejauh mana investasi yang telah ditanamkan mampu memberikan pengembalian keuntungan sesuai dengan yang diharapkan (Fahmi, 2015). Adapun rumus ROA adalah :

$$
\mathrm{ROA}=\frac{\mathrm{EAT}}{\text { Total Assets }}
$$

\subsubsection{Working Capital $\left(\mathrm{X}_{1}\right)$}

Modal kerja diartikan sebagai investasi yang ditanamkan dalam aktiva lancar atau aktiva jangka pendek. Artinya mulai dari kas, bank, surat-surat berharga, piutang, sediaan, dan aktiva lancar lainnya (Kasmir, 2010). Nilai komponen aktiva lancar tersebut menjadi jumlah modal kerja yang dimiliki perusahaan.

$$
\text { Modal Kerja }=\text { Aktiva Lancar }- \text { Hutang Lancar }
$$

\subsubsection{Likuiditas $\left(\mathrm{X}_{2}\right)$}

Rasio lancar yaitu rasio atau perbandingan antara harta lancar (current assets) dengan utang lancar (current liabilities) yang dinyatakan dalam perkalian (Sitanggang, 2014), dengan rumus sebagai berikut

$$
\text { Rasio Lancar }=\frac{\text { Harta Lancar }}{\text { Utang Lancar }}
$$




\subsubsection{Operating Cash Flow $\left(\mathrm{X}_{3}\right)$}

Arus kas dihasilkan oleh kegiatan utama operasi perusahaan (dihasilkan dari penjualan produk dikurangi biaya produksi yang dikeluarkan) (Harmono, 2015).

\subsection{Analisis Regresi Berganda}

Metode yang digunakan dalam penelitian ini menggunakan model regresi berganda. Analisis regresi linier berganda adalah regresi linier untuk menganalisis besarnya hubungan dan pengaruh variabel independen yang jumlahnya lebih dari dua (Suharyadi \& Purwanto, 2004).Persamaan regresi pada penelitian ini dapat dituliskan sebagai berikut:

$$
\mathrm{Y}=\mathrm{a}+\mathrm{b}_{1} \mathrm{X}_{1}+\mathrm{b}_{2} \mathrm{X}_{2}+\mathrm{b}_{3} \mathrm{X}_{3}+\mathrm{e}
$$

Dimana:

Y $\quad=$ Profitabilitas

a $\quad=$ Konstanta

$\mathrm{X} 1=$ Working Capital

$\mathrm{X} 2=$ Likuiditas

X3 = Operating Cash Flow

b1, b2b3 = Koefisien Regresi

$\mathrm{e} \quad=$ Error tern (Kesalahan Pengguna)

\section{HASIL PENELITIAN DAN PEMBAHASAN}

\subsection{Uji Asumsi Klasik}

\subsubsection{Uji Normalitas}

Uji Normalitas dilakukan dengan menggunakan uji grafik dan uji statistik. Pada uji grafik dapat terlihat seperti di bawah ini

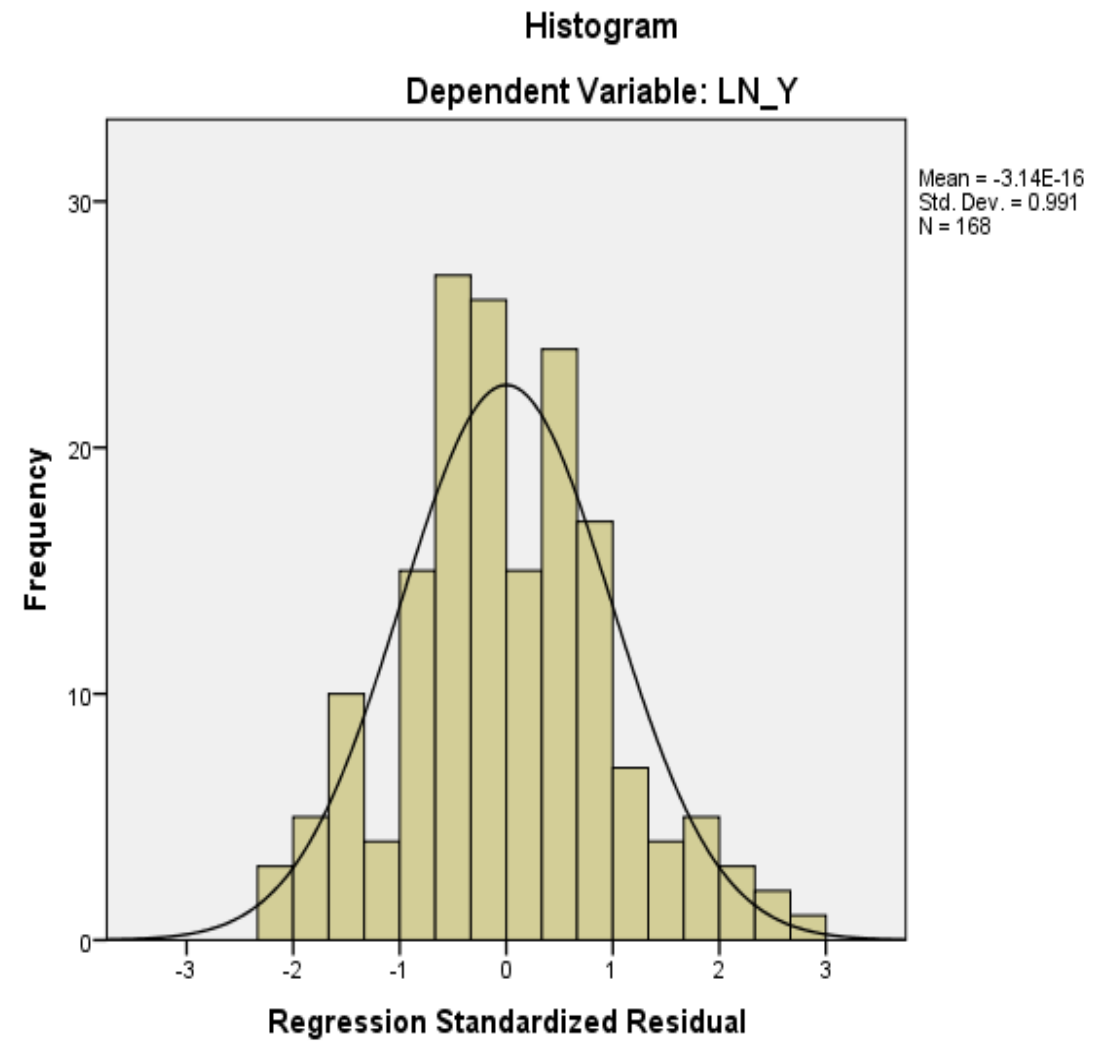

Gambar 1.Uji Normalitas Data 


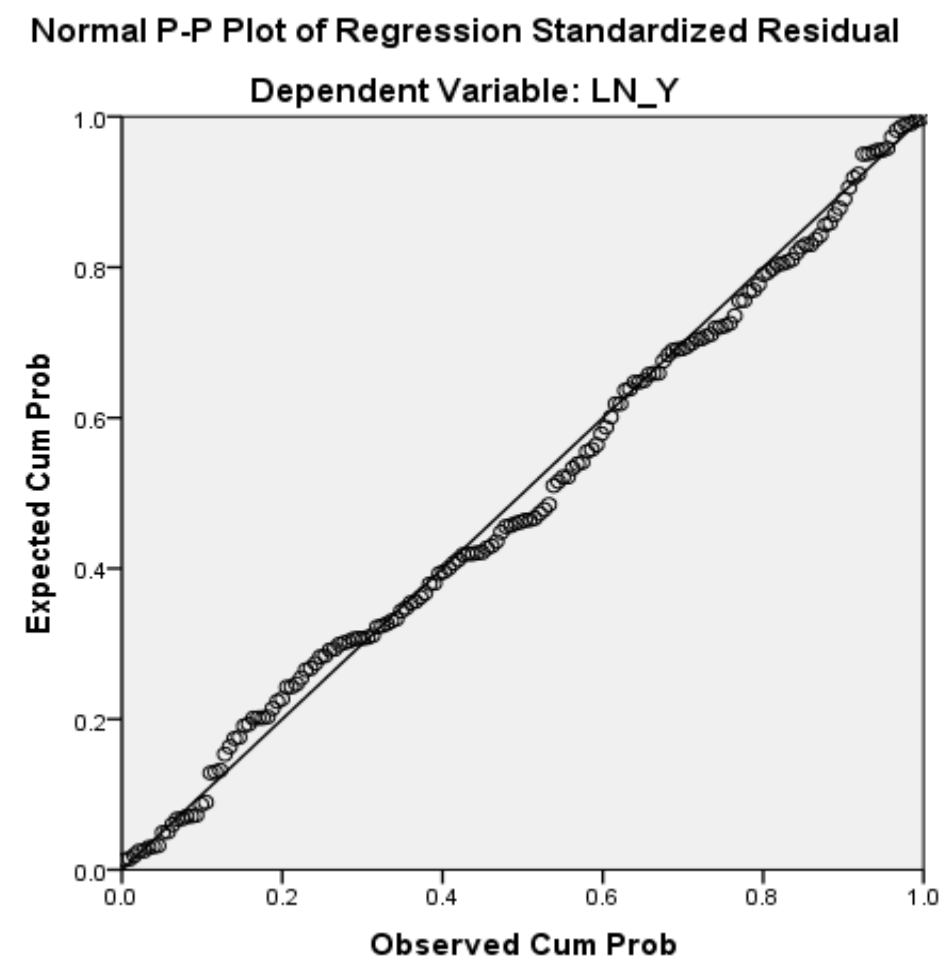

Gambar 2.Uji Normalitas Data P-Plot

Berdasarkan hasil uji grafik yang dilakukan dengan grafik histogram dan uji normality probability plot menunjukkan bahwa data menunjukkan telah memnuhi asumsi berdistribusi normal.

Tabel 2. Uji Normalitas Kolmogorov - Smirnov

\begin{tabular}{|c|c|c|}
\hline \multicolumn{3}{|c|}{ One-Sample Kolmogorov-Smirnov Test } \\
\hline & & $\begin{array}{l}\text { Unstandardized } \\
\text { Residual }\end{array}$ \\
\hline \multicolumn{2}{|l|}{$\mathrm{N}$} & 168 \\
\hline \multirow[t]{2}{*}{ Normal Parameters ${ }^{\mathrm{a}, \mathrm{b}}$} & Mean & .0000000 \\
\hline & Std. Deviation & .09450476 \\
\hline \multirow[t]{3}{*}{ Most Extreme Differences } & Absolute & .052 \\
\hline & Positive & .052 \\
\hline & Negative & -.040 \\
\hline \multicolumn{2}{|l|}{ Kolmogorov-Smirnov Z } & .669 \\
\hline \multicolumn{2}{|l|}{ Asymp. Sig. (2-tailed) } & .761 \\
\hline
\end{tabular}

Dari hasil uji kolmogorov - smirnov diperoleh nilai Asymp.Sig (2-tailed) $(0,761)>$ nilai signifikansi $(0,05)$ maka data berdistribusi normal. Dengan demikian data penelitian berdistribusi normal dan dapat digunakan untuk melakukan uji selanjutnya.

\subsubsection{Uji Multikolinieritas}

Uji Multikolinieritas bertujuan untuk melihat ada tidaknya variabel independen yang memiliki hubungan kuat dengan variabel independen dalam model regresi. Untuk mengetahui ada tidaknya multikomlinieritas dapat dilihat dari nilai Variance Inflation Factor (VIF) dan nilai Tolerance dimana kriterianya yaitu nilai Tolerance $>0,10$ atau sama dengan VIF $<10$. 
Tabel 3. Uji Multikolinieritas

\begin{tabular}{|ll|l|l|}
\hline \multirow{2}{*}{ Model } & \multicolumn{3}{|l|}{ Collinearity Statistics } \\
\cline { 3 - 4 } & & Tolerance & VIF \\
\hline \multirow{3}{*}{1} & (Constant) & & \\
\cline { 3 - 4 } & LN_X1 & .765 & 1.308 \\
\cline { 2 - 4 } & LN_X2 & .773 & 1.294 \\
\cline { 2 - 4 } & LN_X3 & .988 & 1.013 \\
\hline
\end{tabular}

Dari hasil uji multikolinieritas diperoleh bahwa setiap nilai tolerance setiap variabel lebih besar dari 0,10, sedangakan nilai VIF di bawah 10. Maka diperoleh pada model regresi tidak terjadi masalah multikolinieritas.

\subsubsection{Uji Autokorelasi}

Uji Autokorelasi dilakukan untuk melihat apakah dalam suatu model linier ada korelasi antara kesalahan pengganggu pada periode t dengan kesalahan pada periode t-1 (sebelumnya). Uji yan dilakuakan menggunakan uji Durbin Watson $(D W)$.

Tabel 4.Hasil Uji Autokorelasi

\begin{tabular}{|c|c|c|c|c|c|}
\hline Model & $\mathrm{R}$ & R Square & $\begin{array}{l}\text { Adjuste } \\
\text { Square }\end{array}$ & $\begin{array}{l}\text { Rtd. Error of the } \\
\text { Estimate }\end{array}$ & Durbin-Watson \\
\hline 1 & $.516^{\mathrm{a}}$ & .266 & .252 & .09537 & 1.772 \\
\hline
\end{tabular}

Hasil uji autokorelasi diatas menunjukkan nilai-nilai untuk statistik Durbin Watson (d). Dalam tabel DW untuk $\mathrm{k}=4$ dan $\mathrm{n}=168$ maka nilai $\mathrm{du}=1,7996 \mathrm{dan} \mathrm{dl}=1,6992$ dimana nilai DW berada diantara du dan 4-dl (1,7996 < 1,772 < 4-1,6992) dengan kesimpulan bahwa tidak ada autokorelasi positif atau negatif dengan keputusan diterima oleh sebab itu tidak ada autokorelasi positif atau negatif dalam model regresi ini.

\subsubsection{Uji Heterokedastisitas}

Uji heterokedastisitas dilakukan untuk menguji aapakah dalam model regresi terjadi ketidaksamaan variabel residual atau pengamatan ke pengamatan lain. Uji yang digunakan untuk uji heterokedastisitas adalah dengan grafik scatter plot dan uji glesjer.

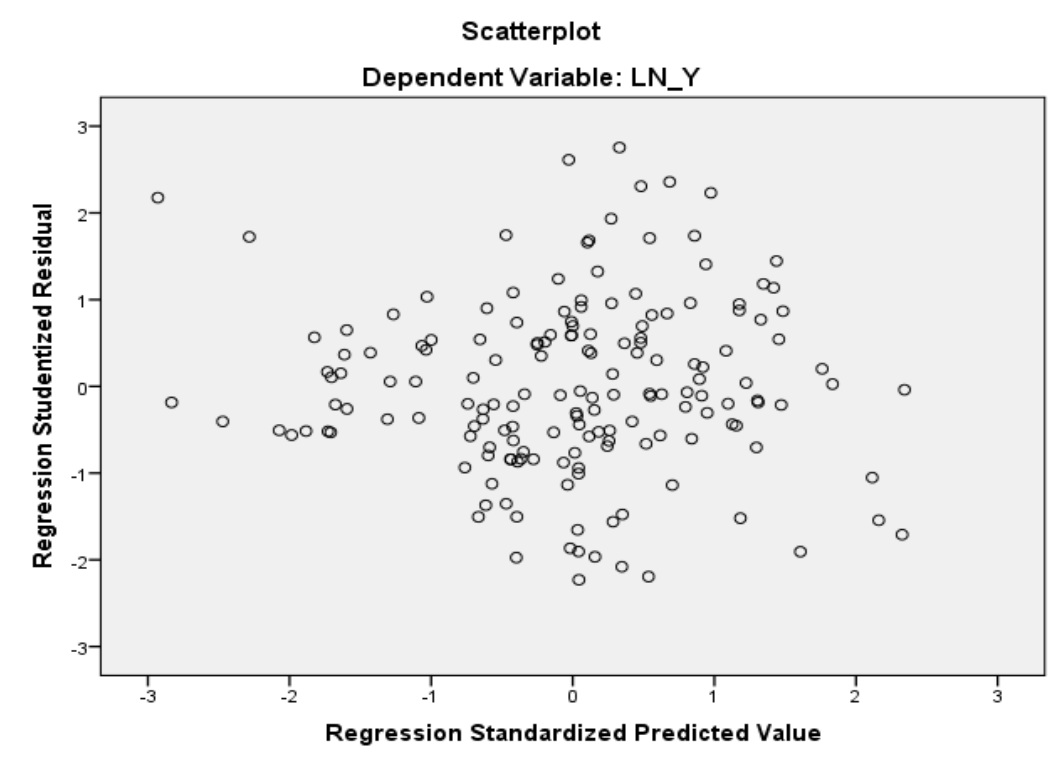

Gambar 3. Uji Scatterplot 
Dilihat dari grafik scatterplot memiliki pola yang menyebar dan sedikit memiliki penumpukan pola yang menghitam serta membentuk pola yang teratur dari grafik tersebut dapat disimpulkan bahwa tidak ada masalah heteroskedastisitas dalam grafik scatterplot ini.

Tabel 5. Uji Glesjer

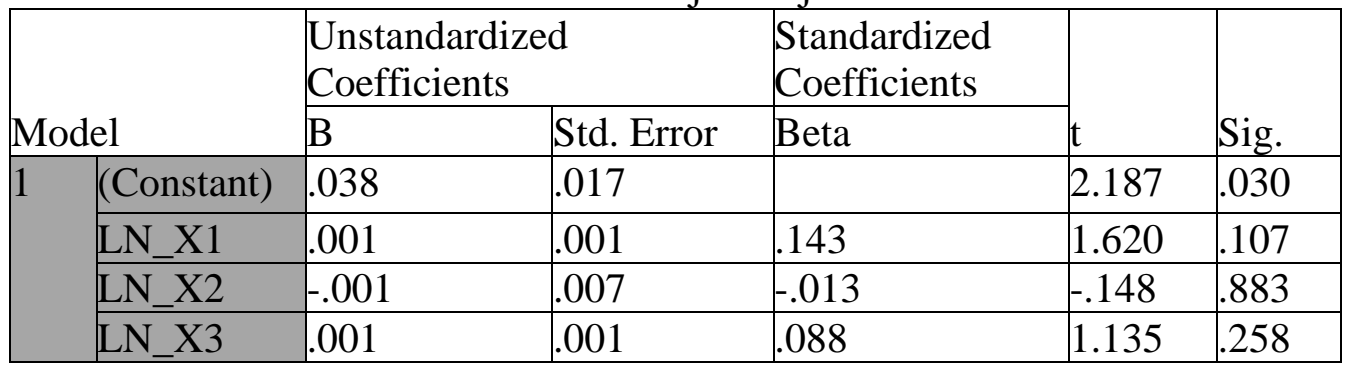

Berdasarkan tabel diatas nilai signifikan dari setiap variabel menunjukkan nilai lebih besar dari 0,05 sehingga dapat disimpulkan bahwa maka uji regresi ini tidak terjadi heterokedastisitas.

\subsection{Pengujian Hipotesis}

\subsubsection{Analisi Regresi Linier Berganda}

Uji analisis regresi linier berganda dilakukan bertujuan untuk mengetahui pengaruh antar variabel independen dengan variabel dependen.

Tabel 6. Hasil Persamaan Regresi Linier Berganda

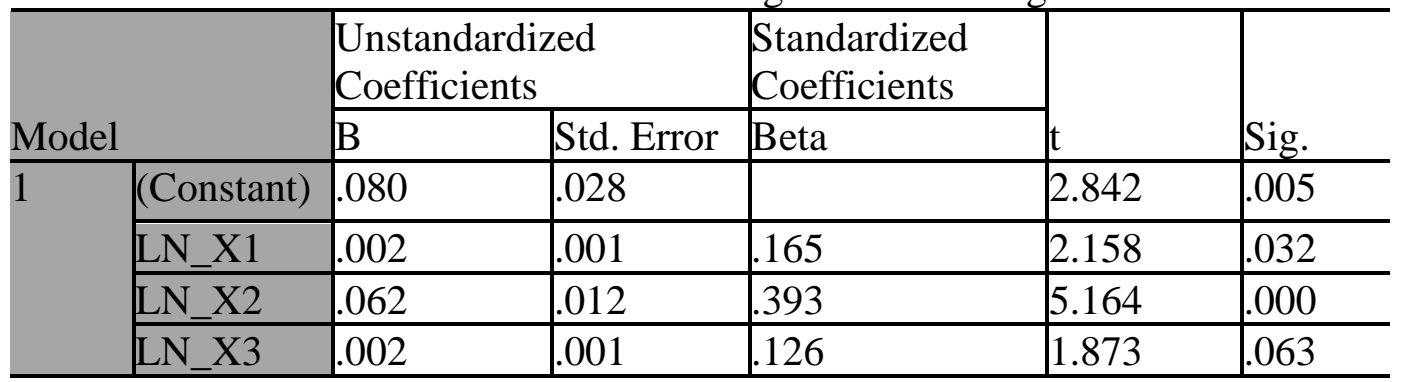

Berdasarkan uji analisis regresi yang dilakukan maka diperoleh model persamaan regresi linier berganda adalah sebagai berikut :

LN_Profitabilitas $=0,080+0,002 \mathrm{LN} \_X 1+0,062 \mathrm{LN} \_X 2+0,002 \mathrm{LN} \_X 3$.

Hasil interprestasi dari regresi tersebut sebagai berikut:

1. Nilai konstanta (a) =0,080 menunjukkan apabila nilai variabel bebas yaitu Working Capital, Likuiditas, Operating Cash Flow bernilai konstan, maka nilai Profitabilitas sebesar 0,080.

2. Koefisien regresi Working Capital (LN_X1) sebesar 0,002 menyatakan bahwa setiap kenaikan sebesar 1 satuan Working Capital, maka akan menyebabkan kenaikan Profitabilitas sebesar 0,002 dengan asumsi variabel lain dianggap konstan.

3. Koefisien regresi Likuiditas (LN_X2) sebesar 0,062 menyatakan bahwa setiap kenaikan sebesar 1 satuan Likuiditas, maka akan menyebabkan kenaikan Profitabilitas sebesar 0,062 dengan asumsi variabel lain dianggap konstan.

4. Koefisien regresi Operating Cash Flow (LN_X3) sebesar 0,002 menyatakan bahwa setiap kenaikan sebesar 1 satuan Operating Cash Flow, maka akan menyebabkan kenaikan Profitabilitas sebesar 0,002 dengan asumsi variabel lain dianggap konstan. 


\subsubsection{Analisis Koefisien Determinasi}

Analisis koefisien determinasi dilakukan untuk melihat sejauh mana variabel independen menjelaskan variabel dependen.

Tabel 7. Uji Koefisien Determinasi

\begin{tabular}{|l|l|l|l|l|}
\hline Model & $\mathrm{R}$ & R Square & Adjusted R Square & Std. Error of the Estimate \\
\hline 1 & $.516^{\mathrm{a}}$ & .266 & .252 & .09537 \\
\hline a. Predictors: (Constant), LN_X3, LN_X2, LN_X1 \\
\hline \multicolumn{2}{|l}{ b. Dependent Variable: LN_Y } \\
\hline
\end{tabular}

Dari hasil Uji yang dilakukan maka diperoleh hasil Uji koefisien determinasi menunjukkan besarnya Adjusted $R$ square sebesar 0,252 yang berarti 25,2\% Profitabilitas dijelaskan oleh Working Capital, Likuiditas, Operating Cash Flow secara bersama-sama. Sisanya sebesar $74,8 \%$ dijelaskan oleh variabel-variabel lain yang tidak diteliti dalam penelitian ini.

\subsubsection{Uji Parsial (Uji t)}

Uji t digunakan untuk mengetahui pengaruh secara parsial variabel bebas (independent) terhadap variabel terikat (dependent) . Diperoleh hasil uji t adalah sebagai berikut :

Tabel 8. Hasil Uji Parsial (Uji t )

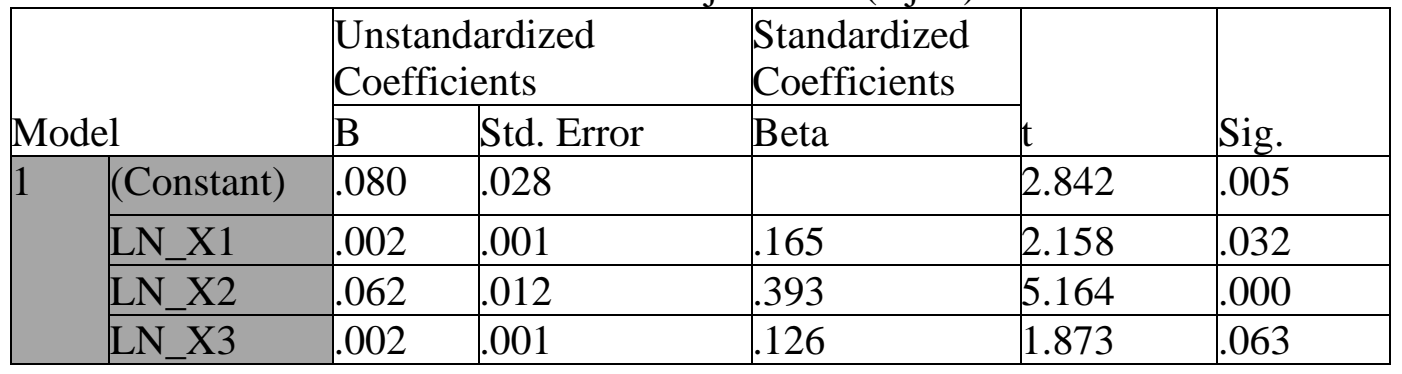

Hasil pengujian statistik secara parsial dengan $\mathrm{df}=\mathrm{n}-\mathrm{k}=168-4=164$ sebagai berikut:

1. Berdasarkan Tabel 8 dijelaskan bahwa variabel Working Capital (LN_X1) mempunyai nilai signifikan $0,032<0,05$ selain itu hasil $t_{\text {hitung }} 2,158>t_{\text {tabel }} 1,97453$ maka $\mathrm{H}_{0}$ ditolak dan $\mathrm{H}_{\mathrm{a}}$ diterima dengan artinya Working Capital berpengaruh positif dan signifikan terhadap Profitabilitas pada perusahaan Aneka Industri, Industri Dasar dan Kimia yang terdapat di Bursa Efek Indonesia tahun 2014-2017.

2. Variabel Likuiditas (LN_X2) mempunyai nilai signifikan $0,000<0,05$ selain itu hasil thitung 5,164>1,97453 maka $\mathrm{H}_{0}$ ditolak dan $\mathrm{H}_{\mathrm{a}}$ diterima dengan artinya Likuiditas berpengaruh positif dan signifikan terhadap Profitabilitas pada perusahaan Aneka Industri, Industri Dasar dan Kimia yang terdapat di Bursa Efek Indonesia tahun 20142017.

3. Variabel Operating Cash Flow (LN_X3) mempunyai nilai signifikan 0,063>0,05 selain itu hasil $\mathrm{t}_{\text {hitung }} 1,873<\mathrm{t}_{\text {tabel, }}, 1,97453$ maka $\mathrm{H}_{0}$ diterima dan $\mathrm{H}_{\mathrm{a}}$ ditolak dengan artinya Operating Cash Flow tidak berpengaruh terhadap Profitabilitas pada perusahaan Aneka Industri, Industri Dasar dan Kimia yang terdapat di Bursa Efek Indonesia tahun 2014-2017. 


\subsubsection{Uji Simultan (Uji F)}

Uji Simultan (Uji F) digunakan untuk menguji variabel bebas (independent) secara bersama - sama memberikan pengaruh kepada variabel terikat (dependent). Berikut ini hasil dari pengujian hipotesis simultan (Uji F)

Tabel 9. Hasil Uji Simultan (Uji F)

\begin{tabular}{|l|l|l|l|l|l|l|}
\hline \multicolumn{7}{|c|}{ ANOVA $^{\mathrm{a}}$} \\
\hline \multirow{2}{*}{ Model } & Sum of Squares & df & Mean Square & F & Sig. \\
\hline \multirow{4}{*}{1} & Regression & .540 & 3 & .180 & 19.786 & $.000^{\mathrm{b}}$ \\
\cline { 2 - 9 } & Residual & 1.492 & 164 & .009 & & \\
\cline { 2 - 8 } & Total & 2.031 & 167 & & & \\
\hline
\end{tabular}

Hasil uji simultan (uji F) diperoleh $F_{\text {hitung }}$ sebesar 19,786 dengan tingkat kepercayaan 95\%, a $=5 \%$, dfl (jumlah variabel -1$)=4-1=3$ dan df $2(n-k)=168-4=164$ maka diperoleh $F_{\text {tabel }}$ sebesar 2,66. Sehingga dapat disimpulkan bahwa $F_{\text {hitung }}>F_{\text {tabel }}(19,786>2,66)$ dengan nilai signifikan $0,000^{\mathrm{b}}$ dibawah nilai 0,05 maka $\mathrm{H}_{0}$ ditolak dan $\mathrm{H}_{\mathrm{a}}$ diterima, yang berarti Working Capital, Likuiditas, dan Operating Cash Flow berpengaruh dan signifikan terhadap Profitabilitas pada perusahaan Aneka Industri, Industri Dasar dan Kimia yang terdapat di Bursa Efek Indonesia tahun 2014-2017.

\section{PEMBAHASAN}

\section{Pengaruh Working Capital terhadap Profitabilitas}

Berdasarkan hasil pengujian uji parsial (uji t) menyatakan bahwa secara parsial Working Capital berpengaruh terhadap Profitabilitas. Dalam hasil pengujian menjelaskan bahwa variabel Working Capital mempunyai nilai signifikan sebesar 0,032 $<0,05$ selain itu hasil $t_{\text {hitung }} 2,158>\mathrm{t}_{\text {tabel }} 1,97453$ maka $\mathrm{H}_{0}$ ditolak dan $\mathrm{H}_{\mathrm{a}}$ diterima dengan artinya Working Capital berpengaruh positif dan signifikan terhadap Profitabilitas pada perusahaan Aneka Industri, Industri Dasar dan Kimia yang terdapat di Bursa Efek Indonesia tahun 2014-2017. Pernyataan dari hasil penelitian di atas juga mendorong teori yang dikemukakan oleh beberapa ahli. Semakin banyak dana yang digunakan sebagai modal kerja seharusnya dapat meningkatkan perolehan laba. Demikian pula sebaliknya, jika dana yang digunakan sedikit, maka laba pun akan menurun. Akan tetapi dalam kenyataannya terkadang kejadiannya tidak selalu demikian (Kasmir, 2012).

\section{Pengaruh Likuiditas terhadap Profitabilitas}

Berdasarkan hasil pengujian uji parsial (uji t) menyatakan bahwa secara parsial Likuiditas berpengaruh terhadap Profitabiltas. Dalam hasil pengujian menjelaskan bahwa variabel Likuiditas mempunyai nilai signifikan sebesar $0,000<0,05$ selain itu hasil thitung 5,164> 1,97453 maka $\mathrm{H}_{0}$ ditolak dan $\mathrm{H}_{\mathrm{a}}$ diterima dengan artinya Likuiditas berpengaruh positif dan signifikan terhadap Profitabilitas pada perusahaan Aneka Industri, Industri Dasar dan Kimia yang terdapat di Bursa Efek Indonesia tahun 2014-2017. Pernyataan dari hasil penelitian di atas juga mendorong teori yang dikemukakan oleh beberapa ahli. Bilamana rasio aktiva lancar atau total aktiva meningkat maka baik profitabilitas maupun resiko yang dihadapi akan menurun (Syamsuddin, 2013).

\section{Pengaruh Operating Cash Flow Terhadap Profitabilitas}

Berdasarkan hasil pengujian uji parsial (uji t) menyatakan bahwa secara parsial Operating Cash Flow tidak berpengaruh terhadap Profitabilitas. Dalam hasil pengujian menjelaskan bahwa variabel Operating Cash Flow mempunyai nilai signifikan sebesar 0,063 $>0,05$ selain itu hasil thitung $1,873<1,97453$ maka $\mathrm{H}_{0}$ diterima dan $\mathrm{H}_{\mathrm{a}}$ ditolak dengan artinya 
Operating Cash Flow tidak berpengaruh dan tidak signifikan terhadap Profitabilitas pada perusahaan Aneka Industri, Industri Dasar dan Kimia yang terdapat di Bursa Efek Indonesia tahun 2014-2017. Pernyataan dari hasil penelitian di atas juga mendorong teori yang dikemukakan oleh beberapa ahli. Kelebihan uang pada suatu saat, melebihi kebutuhan perusahaan, menyebabkan terlalu banyaknya uang yang menganggur, padahal seharusnya uang tersebut dapat dikelola secara lebih optimal lagi untuk kepentingan perusahaan (Rudianto, 2009).

\section{Pengaruh Working Capital, Likuiditas, dan Operating Cash Flow Terhadap Profitabilitas}

Hasil uji simultan (uji F) diperoleh $\mathrm{F}_{\text {hitung }}$ sebesar 19,786 dengan tingkat kepercayaan $95 \%, \mathrm{a}=5 \%$, dfl (jumlah variabel -1$)=3$ dan df $2(\mathrm{n}-\mathrm{k})=164$ maka diperoleh $\mathrm{F}_{\text {tabel }}$ sebesar 2,66. Sehingga dapat disimpulkan bahwa $F_{\text {hitung }}>F_{\text {tabel }}(19,786>2,66)$ dengan nilai signifikan $0,000^{\mathrm{b}}$ dibawah nilai 0,05 maka $\mathrm{H}_{0}$ ditolak dan $\mathrm{H}_{\mathrm{a}}$ diterima, yang berarti efisiensi Working Capital, Likuiditas dan Operating Cash Flow berpengaruh dan signifikan terhadap Profitabilitas pada perusahaan Aneka Industri, Industri Dasar dan Kimia yang terdapat di Bursa Efek Indonesia tahun 2014-2017. Oleh sebab itu laba dan hutang merupakan indikator penting yang selalu menjadi patokan untuk perusahaan.

\section{KESIMPULAN}

Berdasarkan hasil penelitian dan pembahasan yang telah diuraikan pada bab sebelumnya, maka peneliti menarik kesimpulan sebagai berikut:

1. Working Capital berpengaruh positif terhadap Profitabilitas pada perusahaan Aneka Industri, Industri Dasar dan Kimia yang terdapat di Bursa Efek Indonesia tahun 2014-2017.

2. Likuiditas berpengaruh positif terhadap Profitabiltas pada perusahaan Aneka Industri, Industri Dasar dan Kimia yang terdapat di Bursa Efek Indonesia tahun 2014-2017.

3. Operating Cash Flow tidak berpengaruh terhadap Profitabilitas pada perusahaan Aneka Industri, Industri Dasar dan Kimia yang terdapat di Bursa Efek Indonesia tahun 2014-2017.

4. Working Capital, Likuiditas dan Operating Cash Flow berpengaruh terhadap Profitabilitas pada perusahaan Aneka Industri, Industri Dasar dan Kimia yang terdapat di Bursa Efek Indonesia tahun 2014-2017, Uji koefisien determinasi menunjukkan besarnya Adjusted $R$ Square sebesar 0,252 yang berarti 25,2\% Profitabilitas dijelaskan oleh Working Capital, Likuiditas, dan Operating Cash Flow. Sisanya sebesar 74,8\% dijelaskan oleh variabelvariabel lain yang tidak diteliti dalam penelitian ini, seperti Quick Ratio, Net Profit Margin, dan Struktur Modal.

\section{SARAN}

Bagi peneliti selanjutnya sebaiknya menambahan variabel yang mempengaruhi profitabilitas karena variabel yang digunakan oleh peneliti saat ini hanya memberikan nilai Adjusted $R$ Square yang kecil yaitu sebesar 25,2. Variabel yang mungkin mempengaruhi adalah seperti Quick Ratio, Net Profit Margin, dan Struktur Modal. Diharapkan juga bagi peneliti selanjutnya untuk melakukan penelitian pada perusahaan yang berbeda.

\section{DAFTAR PUSTAKA}

Fahmi, I. (2015). Pengantar Manajemen Keuangan. Bandung: Alfabeta.

Fahmi, I. (2016). Pengantar Manajemen Keuangan. Bandung: Alfabeta.

Hantono. (2017). Konsep Analisis Laporan Keuangan Dengan Pendekatan Rasio Dan SPSS.

Yogyakarta: Deepublish.

Harmono. (2015). Manajemen Keuangan (1st ed.). Jakarta: Bumi Aksara. 
Hery. (2014). Analisis Kinerja Manajemen. Jakarta: Grasindo.

Hery. (2015). Analisis Laporan Keuangan (1st ed.). Yogyakarta: CAPS (Center for Academic Publishing Service).

Ikhsan, Alfurkaniati, S., L, S., \& Dalimunthe, M. I. (2016). Analisis Laporan Keuangan (1st ed.). Medan: Madenatera.

Jumingan. (2015). Analisis Laporan Keuangan (5th ed.). Jakarta: Bumi Aksara.

Kamaludin, I. (2012). Manajemen Keuangan. Bandung: Mandar Maju.

Kasmir. (2010). Analisis Laporan Keuangan (3rd ed.). Jakarta: Rajagrafindo Persada.

Kasmir. (2012). Analisis Laporan Keuangan (5th ed.). Jakarta: Rajagrafindo Persada.

Munawir. (2014). Analisis Laporan Keuangan (4th ed.). Yogyakarta: Liberty.

Rudianto. (2009). Pengantar Akuntansi. Jakarta: Erlangga.

Sitanggang. (2014). Manajemen Keuangan Perusahaan (2nd ed.). Jakarta: Mitra Wacana Media.

Sjahrial, D., \& Purba, D. (2013). Analisis Laporan Keuangan. Jakarta: Mitra Wacana Media. Sugiono, A. (2016). Panduan Praktis Dasar Analisa Laporan Keuangan. Jakarta: Grasindo. Sugiyono. (2016). Metode Penelitian Kuantitatif, Kualitatif, dan R\&D. Bandung: Alfabeta. Suharyadi, \& Purwanto. (2004). Metodologi Penelitian. Gramedia Pustaka Utama.

Syamsuddin, L. (2013). Manajemen Keuangan Perusahaan (12th ed.). Jakarta: Rajagrafindo Persada.

Utari, D., Purwanti, A., \& Prawironegoro, D. (2014). Manajemen Keuangan : Kajian Praktik dan Teori dalam Mengelola Keuangan Organisasi Perusahaan. Jakarta: Mitra Wacana Media. 